\title{
INFLUENCE OF FOCUSING TUBE WEAR ON VIBRATIONS AND SURFACE ROUGHNESS
}

\author{
Agáta Radvanská, Pavol Hreha, Lucia Knapčíková, Jana Petrů, Tomáš Zlámal, Peter Monka
}

Original scientific article

The paper deals with the study of the focusing tube wear influence on surface quality and vibrations produced by abrasive waterjet by means of experiments design. The experiments deal with evaluation of the influence of focusing tube wear on surface quality and parameters of vibration generated by abrasive waterjet cutting. The main task of the first experiment was to study the significance of four selected factors of independent variables (focusing tube wear, traverse rate, abrasive mass flow rate and pressure) by full factorial analysis at two levels. The aim of the second experiment was to study the influence of focusing tube wear on the vibration parameters. It has been observed that focusing tube wear has a significant negative influence on surface quality and parameters of vibration.

Keywords: abrasive waterjet; focusing tube; surface quality; vibration

\section{Utjecaj istrošenosti fokusirajuće cijevi na vibracije i površinsku hrapavosti}

Rad se bavi ispitivanjem utjecaja istrošenosti fokusirajuće cijev na kvalitetu površine i vibracije koje proizvodi abrazivni vodeni mlaz, putem eksperimenata. Pokusi se bave procjenom utjecaja istrošenosti fokusirajuće cijevi na kvalitetu površine i parametre vibracija nastalih rezanjem abrazivnim vodenim mlazom. Glavni zadatak prvog eksperimenta bio je proučiti značaj četiri odabrana faktora nezavisnih varijabli (istrošenost fokusirajuće cijevi, brzina prijelaza, protok abrazivne mase i tlak) potpunom faktorijalnom analizom na dvije razine. Cilj drugog eksperimenta bio je istražiti utjecaj istrošenosti fokusirajuće cijevi na parametre vibracija. Uočeno je da istrošenost fokusirajuće cijevi ima značajan negativan utjecaj na kvalitetu površine i parametre vibracije.

Ključne riječi: abrazivni vodeni mlaz; fokusirajuća cijev; kvaliteta površine; vibracije

\section{Introduction}

Abrasive waterjet technology (AWJ) is a cold cutting process which is a rapidly developing technology that is used in industry as a basic tool for various applications [1 : 3 ], including plate profile cutting, machining of a range of metallic $[4 \div 7]$ or non-metallic materials $[2,3]$ by an abrasive waterjet tool that is specific in its consistence of three phases (liquid, solid and fluid) formed in focusing tube [8] (Fig. 1). The focusing tube needs to be replaced depending on the cutting quality requirements [9]. But the focusing tube is one of the most wearable parts on time in the abrasive waterjet technology, whose consequence is increasing of the inner diameter of the focusing tube. As the inner diameter of the focusing tube increases, there is a higher probability that it affects the quality of the AWJ tool - the density and solid phase orientation in liquid phase entering the cutting process of materials $[10,11]$. Hence from the machining point of view it is useful to know the influence of focusing tube inner diameter on surface quality which has not been exactly explained. Therefore, determining was investigated influence of focusing tube diameter on surface roughness of stainless steel and aluminium. During cutting the accompanying phenomenon like acoustic emission and vibration occurs [12 $\div 15]$. Therefore in the second additional experiment influence of focusing tube diameter was monitored via vibration.

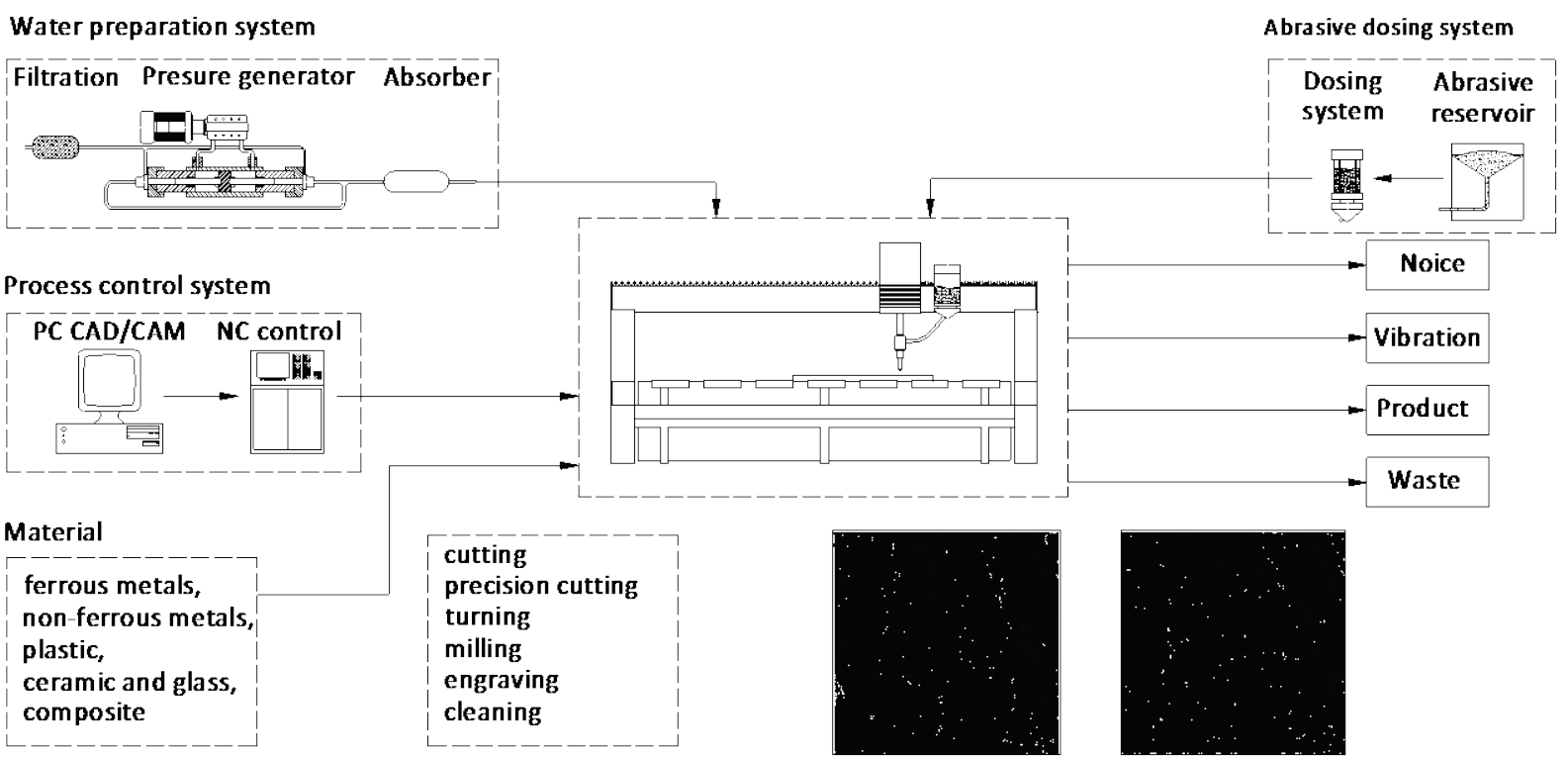

Figure 1 Technology process scheme and the most wearable part - focusing tube that affects the parameters of surface roughness, vibration and the noise 


\section{Related works and problem definition}

Technological process of cutting by means of abrasive waterjet is provided at production equipment by means of the tool - abrasive waterjet, whose properties characteristics are not degraded during operation time in contrary to conventional cutting tool. But in case of the abrasive waterjet technology, the most wearable part of the AWJ equipment is the focusing tube, where the abrasive waterjet stream is formed.

Focusing tube amortization is evident after a relatively long time interval. In scheme (Fig. 1), obtained in cooperation with DRC, Ltd. company in Prešov there are illustrated wear profiles, increase of inner diameter of focusing tube by each wear degree. Wear of focusing tube results in wear and impact of the abrasive particles on the mixing process at the focusing tube wall.

According to the measured deviation of the cutting accuracy there have been estimated five degrees (Fig. 2) of the focusing tube wear, where the size of the inner diameter $d_{\mathrm{f}}$ is estimated in the following tolerances by means of empirical knowledge of the operator (Tab. 1).

Table 1 Wear degree of focusing tube empirically estimated

\begin{tabular}{|c|c|}
\hline Wear degree & $d_{\mathrm{f}}(\mathrm{mm})$ \\
\hline 1 & 0,89 to 0,90 \\
\hline 2 & 0,91 to 1,00 \\
\hline 3 & 1,01 to 1,10 \\
\hline 4 & 1,11 to 1,20 \\
\hline 5 & 1,21 to 1,30 \\
\hline
\end{tabular}

Depending on the abrasive mass flow rate $m_{\mathrm{a}}$ and the operation time $t$ the degrees of wear are different (Tab. 2). The dependence is obtained by means of empirical observation of the operator at the company where the experiments were provided. The pressure of water was constant $p=380 \mathrm{MPa}$.

Table 2 Wear degree of focusing tube depending on abrasive mass flow rate $m_{\mathrm{a}}(\mathrm{g} / \mathrm{min})$

\begin{tabular}{|c|c|c|c|c|c|}
\hline$m_{\mathrm{a}}(\mathrm{g} / \mathrm{min})$ & \multicolumn{5}{|c|}{ Elapsed time (Hours) } \\
\hline 250 & 1 & 1 & 2 & 2 & 3 \\
\hline 300 & 1 & 1 & 2 & 3 & 3 \\
\hline 350 & 1 & 1 & 2 & 3 & 4 \\
\hline 400 & 1 & 2 & 3 & 4 & 5 \\
\hline 450 & 1 & 2 & 3 & 4 & 5 \\
\hline 500 & 2 & 3 & 4 & 5 & 5 \\
\hline 550 & 2 & 4 & 5 & 5 & 5 \\
\hline
\end{tabular}

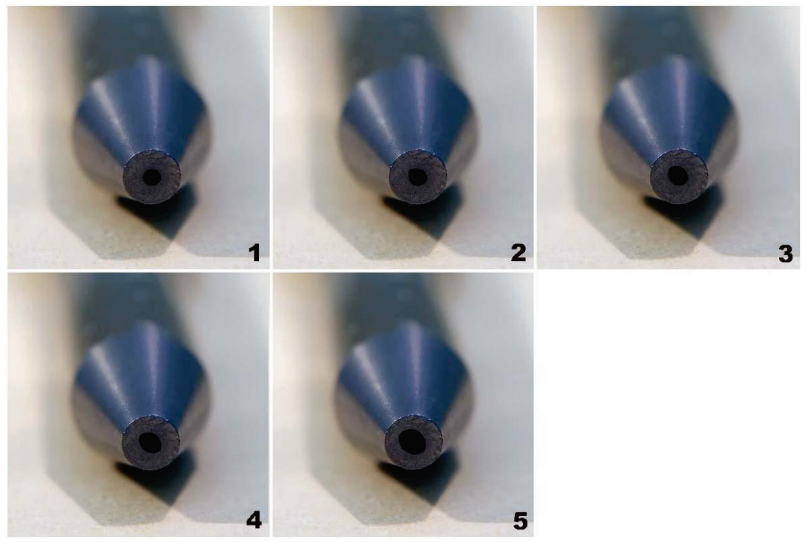

Figure 2 Wear profiles of carbide focusing tube

\section{Experimental set up}

The evaluation of the quality of machined surface is based on the judgment of its roughness parameter Ra. Theoretical roughness depends exclusively on AWJ tool geometry and the applied process of machining whereas the real roughness appears as the result of theoretical roughness though with bigger or less occasional roughness provoked by the investigated factor - focusing tube wear with interaction of abrasive mass flow rate $m_{\mathrm{a}}$ $(\mathrm{g} / \mathrm{min})$, traverse speed $v(\mathrm{~mm} / \mathrm{min})$ and pressure $p(\mathrm{MPa})$. In order to investigate the influence of the AWJ factors on surface profile parameter $R a$, full factorial design for four independent variables has been designed, where is statistically simulated the influence of the focusing tube wear with interaction of abrasive mass flow rate $m_{\mathrm{a}}$ $(\mathrm{g} / \mathrm{min})$, traverse speed $v(\mathrm{~mm} / \mathrm{min})$ and pressure $p(\mathrm{MPa})$. Full factorial analysis was used to obtain the combination of values that can optimize the response, which allows one to design a minimal number of experimental runs [16]. Four factors submitted for the analysis in the factorial design of each constituent levels $[-1 ;+1]$ are listed in tables 3, 4, where the experimental conditions for AISI 304 and aluminium are defined. Surface profile parameter belongs to the basic micro geometrical characteristics of the surface produced by abrasive waterjet [17]. The values of the average roughness parameter $R a$ determine the necessity of the further finishing of the surface and the total utilization of the material $[18 \div 21]$.

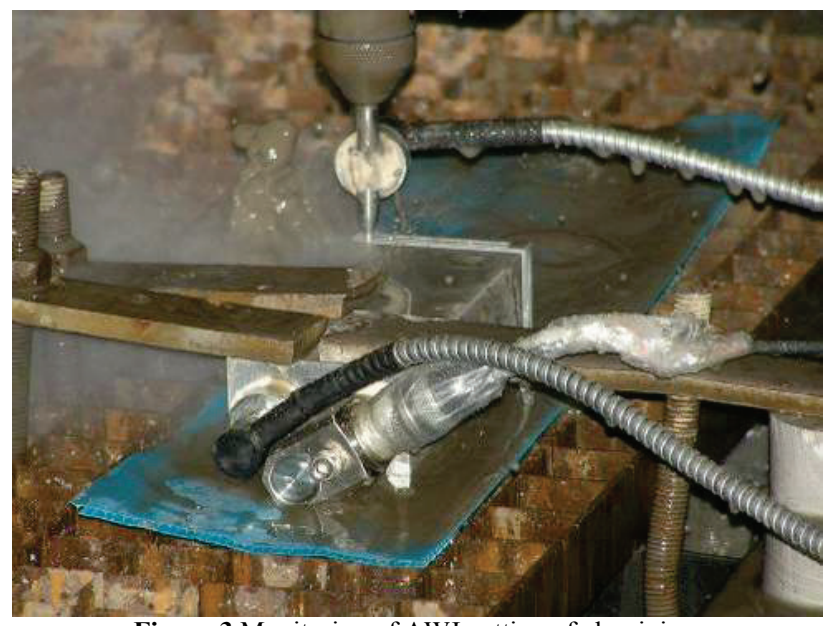

Figure 3 Monitoring of AWJ cutting of aluminium

The experiments were carried out by the analysis using Statistica 7.0 and Matlab to estimate the responses of the surface profile parameter average roughness $R a$. A two dimensional abrasive waterjet machine Wating, was used in this work with the following specification: work table $x$-axis $2000 \mathrm{~mm}, y$-axis $3000 \mathrm{~mm}$. The high-pressure intensifier pump, Ingersoll-Rand Streamline model, with maximum pressure $380 \mathrm{MPa}$ was used. As a cutting head an Ingersoll-Rand Autoline cutting head was used. Vibration measurement (data collection) was provided during abrasive water jet cutting of aluminium. Vibration sensors were mounted on the workpiece and the focusing tube, and were attached to the adapter by a threaded screw M6. The absolute vibration was recorded - the surface vibration sensors were installed on site. The 
measurements were carried out by using new focusing tube and wear focusing after 60 hours of operation. Vibration was recorded by different traverse rate of cutting head.

Data were collected by measuring system NI PXI (type of measuring card PXI 4472B, 8-channel simultaneous collection, 24 bit A/D converter, assay frequency into $102 \mathrm{kHz}$, dynamic range $110 \mathrm{~dB}$ ) and frequency analyzer Microlog GX-S.

Data analysis was transferred by Lab View Professional Development System, including Sound and
Vibration Toolset and Order Analysis Toolset, and Aptitude Analyst SKF Condition Monitoring.

As sensors, accelerometers were used of PCB IMI type 607A11 with integrated cable (sensitivity of 100 $\mathrm{mV} / \mathrm{g}$, frequency range up to $10 \mathrm{kHz}$ ). Measuring methods for analysis signal, velocity frequency area from $0,5 \mathrm{~Hz}$ to $500 \mathrm{~Hz}$, FFT and Time analysis, detection signal RMS, unit $\mathrm{mm} / \mathrm{s}$, acceleration frequency area up to $5 \mathrm{kHz}$ and Time analysis, detection signal Peak, unit $\mathrm{g}$ $\left(9,81 \mathrm{~m} / \mathrm{s}^{2}\right)$.

Table 3 Experimental conditions for stainless steel AISI 304

\begin{tabular}{|c|c|l|c|c|c|}
\hline \multirow{2}{*}{ No. } & \multicolumn{2}{|c|}{ Factors } & \multicolumn{2}{c|}{ Factors Level } \\
\cline { 2 - 6 } & Variable & Terminology & Dimension & -1 & +1 \\
\hline 1 & $x_{1}$ & Focusing tube diameter $d_{\mathrm{f}}$ & $\mathrm{mm}$ & 1 & 1,2 \\
\hline 2 & $x_{2}$ & Abrasive mass flow rate $m_{\mathrm{a}}$ & $\mathrm{MPa}$ & 300 & 500 \\
\hline 3 & $x_{3}$ & Pressure $p$ & $\mathrm{~mm} / \mathrm{min}$ & 200 & 350 \\
\hline 4 & $x_{4}$ & Traverse speed $v$ & 70 & 120 \\
\hline
\end{tabular}

Table 4 Experimental conditions for aluminium

\begin{tabular}{|c|c|l|c|c|c|}
\hline \multirow{2}{*}{ No. } & \multicolumn{2}{|c|}{ Factors } & \multicolumn{2}{c|}{ Factors Level } \\
\cline { 2 - 6 } & Variable & Terminology & Dimension & -1 & +1 \\
\hline 1 & $x_{1}$ & Focusing tube diameter $d_{f}$ & $\mathrm{~mm} / \mathrm{mm}$ & 1 & 1,2 \\
\hline 2 & $x_{2}$ & Abrasive mass flow rate $m_{a}$ & $\mathrm{MPa}$ & 200 & 400 \\
\hline 3 & $x_{3}$ & Pressure $p$ & $\mathrm{~mm} / \mathrm{min}$ & 100 & 200 \\
\hline 4 & $x_{4}$ & Traverse speed $v$ & 350 & 200 \\
\hline
\end{tabular}
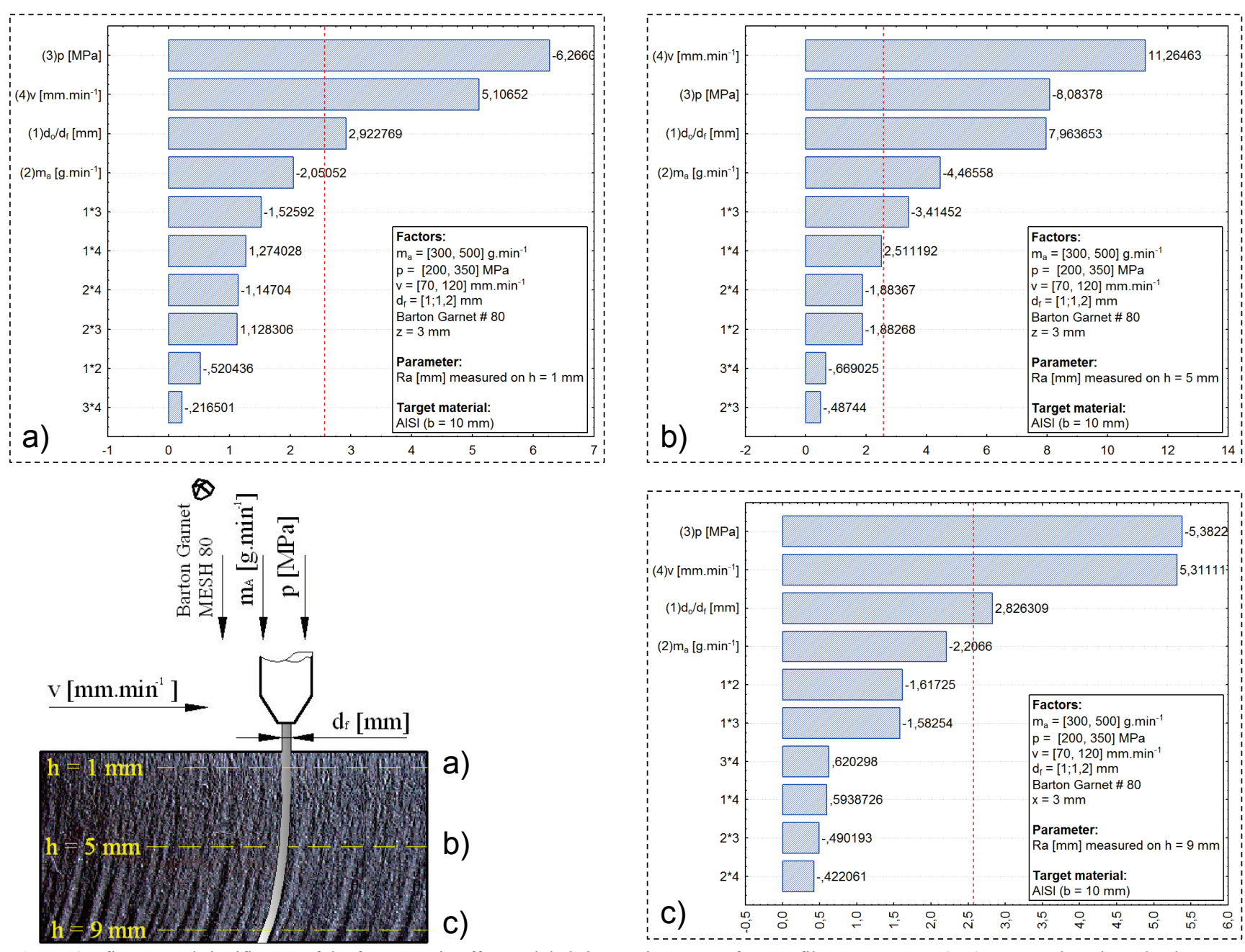

Figure 4 Influence and significance of the factors main effect and their interactions on surface profile parameter $R a$ ( $\mu \mathrm{m}$ ) measured on three depth traces a) $h=1 \mathrm{~mm}$, b) $h=5 \mathrm{~mm}$, c) $h=9 \mathrm{~mm}$ of the stainless steel AISI 304, b $=10 \mathrm{~mm}$, interpreted by means of Pareto Charts. 


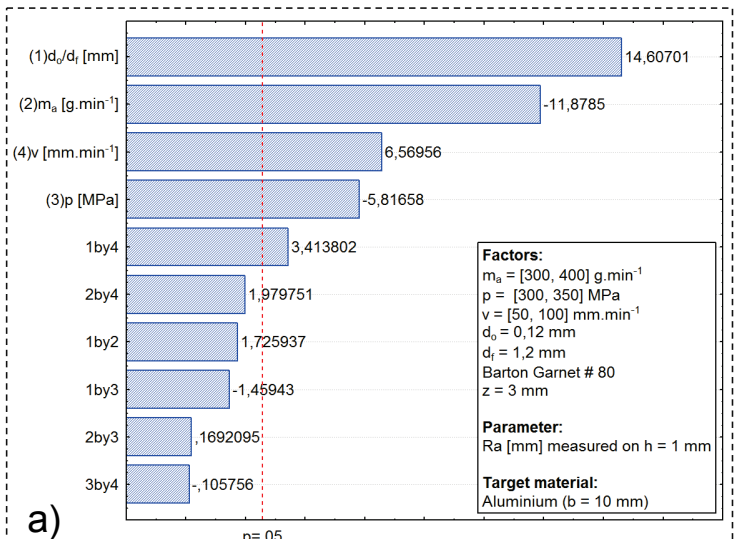

a)
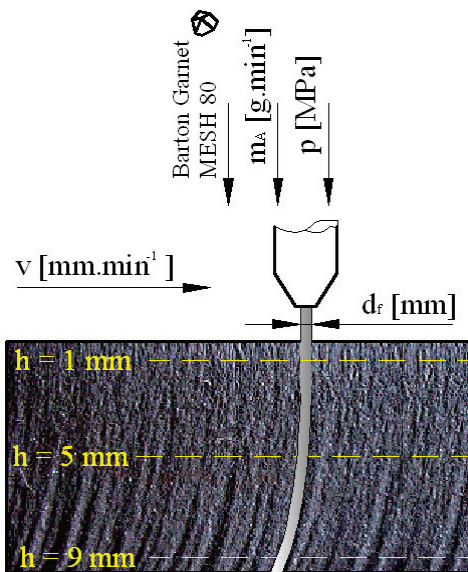

a)

b)

c)
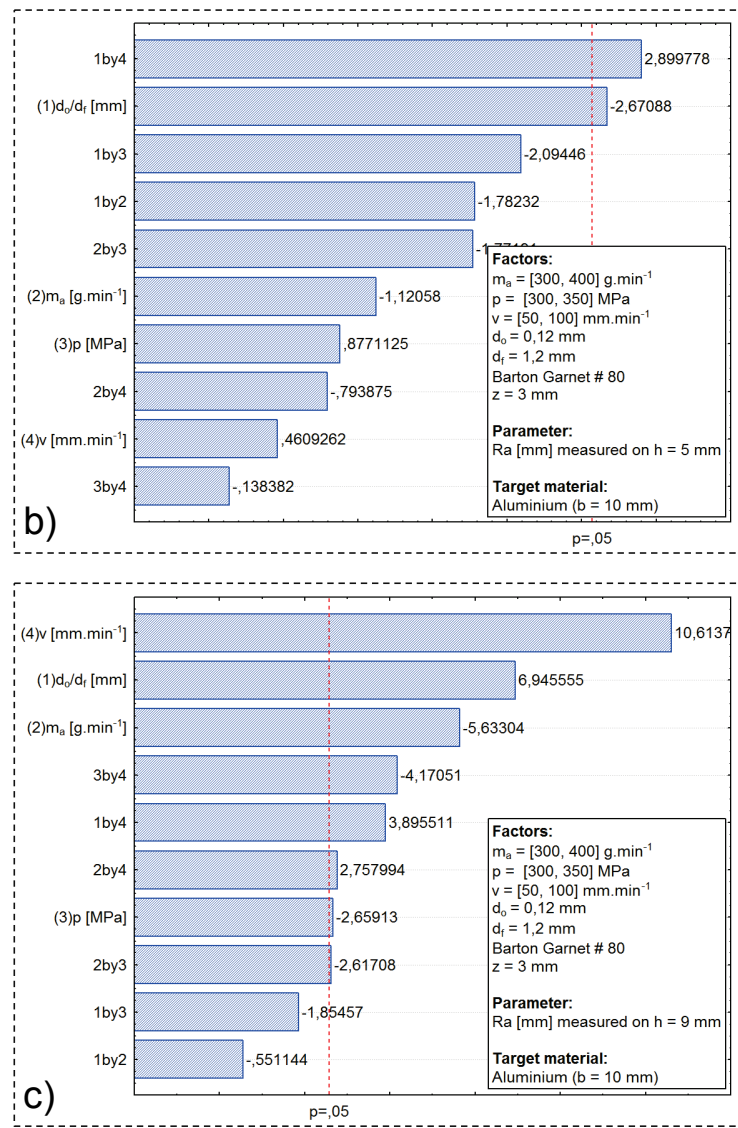

Figure 5 Influence and significance of the factors main effect and their interactions on surface profile parameter Ra [ $\mu \mathrm{m}]$ measured on three depth traces a) $h=1 \mathrm{~mm}$, b) $h=5 \mathrm{~mm}$, c) $h=9 \mathrm{~mm}$ of the aluminium $b=10 \mathrm{~mm}$, interpreted by means of Pareto Charts.

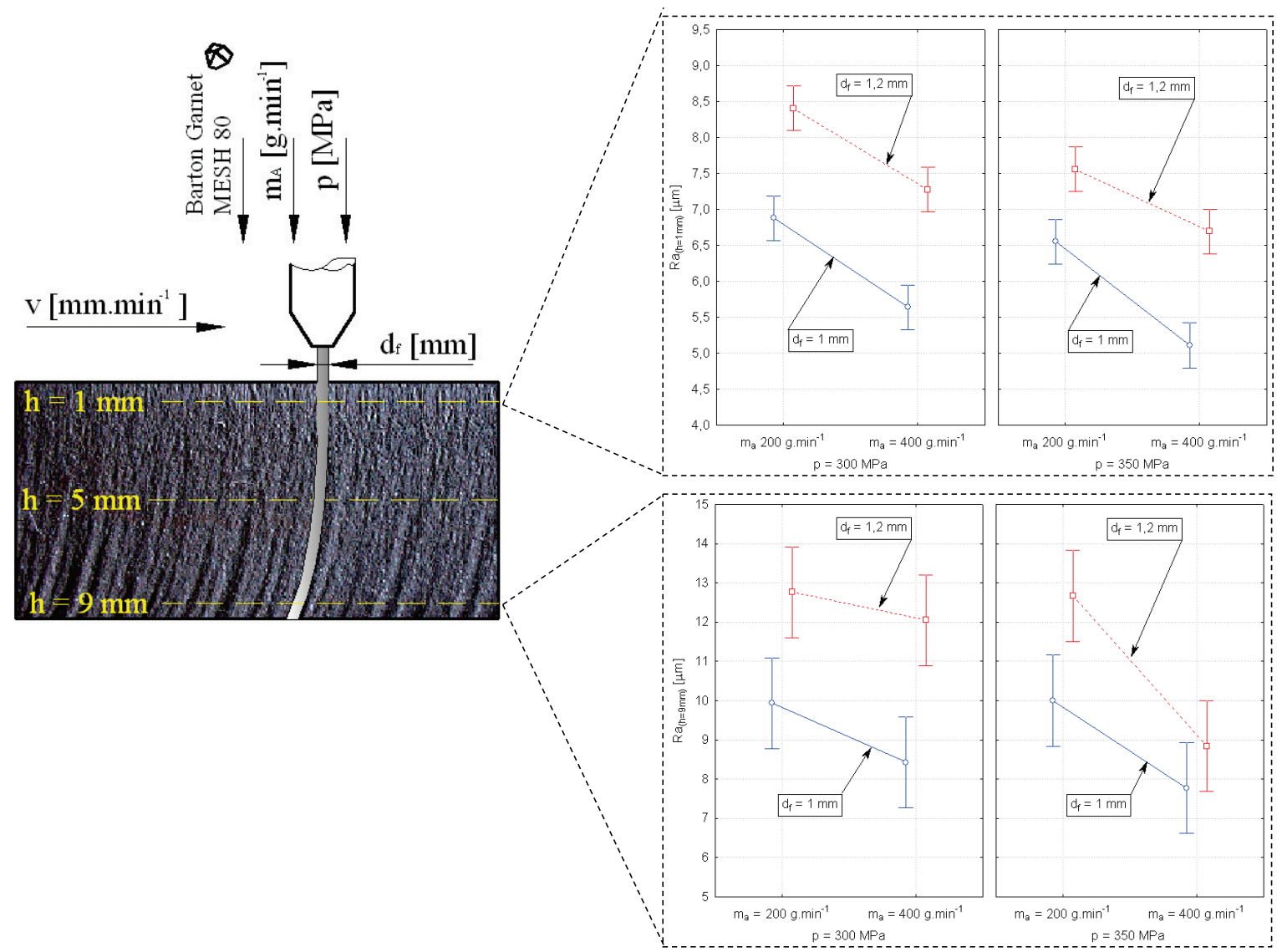

Figure 6 Statistical modelling of the focusing tube wear influence $d_{\mathrm{f}}(\mathrm{mm})$ with interaction of abrasive mass flow rate $m_{\mathrm{a}}(\mathrm{g} / \mathrm{min})$ and pressure $p(\mathrm{MPa})$ at mean interval value of feed rate $v=150 \mathrm{~mm} / \mathrm{min}$ and their influence on surface profile parameter $R a$ [ $\mu \mathrm{m}]$ on depth traces $h=1 \mathrm{~mm}$ and $h=9 \mathrm{~mm}$, experimental material aluminium $b=10 \mathrm{~mm}$. 


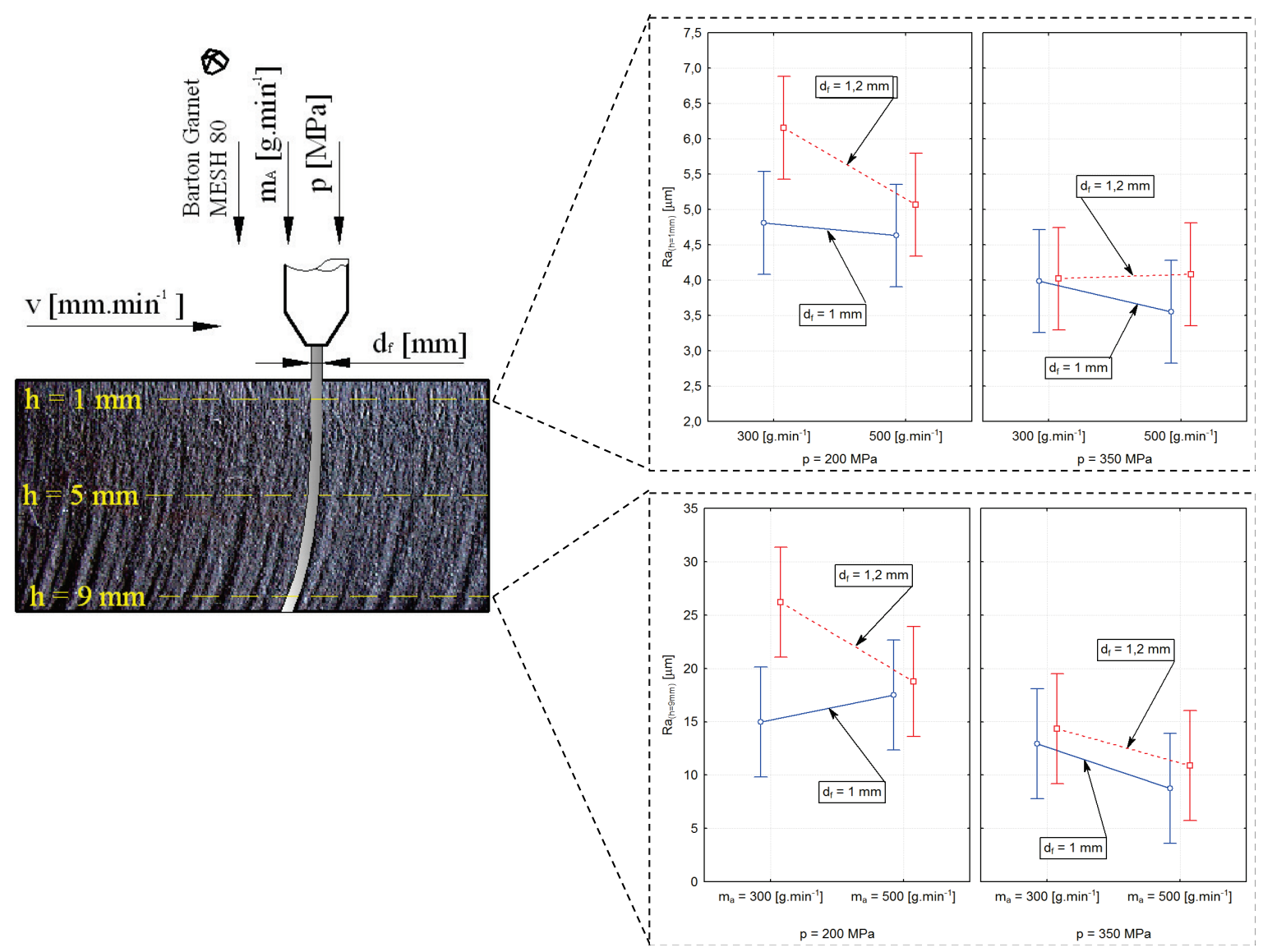

Figure 7 Statistical modelling of the focusing tube wear influence $d_{f}[\mathrm{~mm}]$ with interaction of abrasive mass flow rate $m_{\mathrm{a}}(\mathrm{g} / \mathrm{min})$ and pressure $p(\mathrm{MPa})$ at mean interval value of feed rate $v=150 \mathrm{~mm} / \mathrm{min}$ and their influence on surface profile parameter $R a(\mu \mathrm{m})$ on depth traces $h=1 \mathrm{~mm}$ and $h=9 \mathrm{~mm}$, experimental material stainless steel AISI $304, b=10 \mathrm{~mm}$.

\section{Results and discussion}

\subsection{Focusing tube wear vs surface roughness}

Quantitative description of the conditions effects on average roughness was performed. Response surface methodology is an empirical modelling technique used to evaluate the relationship between a set of controllable experimental factors and observed results.

The normality of experimental measured data was tested according to Shapiro-Wilkson parametrical test criteria for its good power properties as compared to a wide range of alternative tests. Shapiro-Wilkson test proved that experiments (repeated measurement) did not exceed the critical value $W \alpha=0,788$ for $n=4$ and $\alpha=$ 0,05 , respectively. Probability value $\mathrm{p}$ is out of range, as preferred significance level $\alpha$, hence we can accept the null hypothesis of normal distribution measurements repeatability. Repeated measurements have normal Gauss distribution that enables the use of parametrical Grubbs test of remoteness measurement. For the rest of experiments it was necessary to apply the Dixon's non parametric test of remote measurements presence.

The normality of experimental measured data has been tested according to Shapiro-Wilkson test criteria for its good power properties as compared to a wide range of alternative tests. Regression coefficients have been calculated by means of Statistica 7 . The regression coefficients and equations obtained after analysis of variance give the level of significance of variable parameters tested according to Student's t-test. Obtained regression coefficients that show no statistical significance have been rejected from further evaluation. These results can be further interpreted in the Pareto Charts, which graphically display the magnitudes of the effects from the results obtained. Figs. 7 and 8 graphically display the influence magnitudes of the evaluated factors main effect and their interactions on surface profile parameter $R a[\mu \mathrm{m}]$ measured on three depth traces a) $h=$ $1 \mathrm{~mm}$, b) $h=5 \mathrm{~mm}$, c) $h=9 \mathrm{~mm}$ of stainless steel AISI 304, $b=10 \mathrm{~mm}$ (Fig. 7) and aluminium (Fig. 8), which are sorted from the largest to the smallest, from obtained results. The most important factors affecting the parameter average roughness $R a$. By consideration of these Pareto Charts can be easily identified causalities, that most deteriorate the quality process and separate them from less significant.

From Pareto analysis it results that influence of focusing tube wear on surface profile parameter $R a$ is significant on all depth traces. On depth trace (Fig. 6) $h=$ $1 \mathrm{~mm}$, factor $d_{\mathrm{f}}$ is the most significant at the cutting of aluminium. The trace line in shallow depth has been chosen in order to verify the surface profile parameter in shallow depths, where is coded information about first contact of abrasive waterjet stream with target material as well as the whole technology. On the depth of $5 \mathrm{~mm}$ the parameter average roughness is affected by interaction of two factors: focusing tube diameter and traverse speed (Fig. 8b). The second most significant factor which significantly affects the measured parameter $R a$ is the main effect of the factor - diameter of the focusing tube. It follows from the results that the most important factors that affect the surface quality parameters at the cutting of 
the soft materials are mainly the focusing tube diameter at the shallow depths and the traverse speed, abrasive mass flow rate, at depth of $9 \mathrm{~mm}$ that is connected with reduction of the kinetic energy of the stream, which is absorbed by eroded material.

At depth trace $h=5 \mathrm{~mm}$ (Fig. $8 \mathrm{~b}$ ) it is evident that at the cutting of aluminium of significance is the interaction of the focusing tube $d_{\mathrm{f}}$ and traverse speed $v(\mathrm{~mm} / \mathrm{min})$, which confirms that diameter of the abrasive waterjet stream is deformed with an increase of the traverse speed. At depth of $9 \mathrm{~mm}$ is effect of the focusing tube significant, after traverse speed $v$. In that case we can assume, that at the cutting of the soft materials as aluminium, the surface profile parameter $R a$ is mainly affected by focusing tube diameter, because the less diameter of the focusing tube, or the less wear of the focusing tube is, the concentration of the abrasive particles on peripheral part of the stream will be higher, which will mean relatively smooth cutting of the material. Opposite situation has been observed at the experimental cutting of the austenitic stainless steel AISI 304. In that case the dominant factor is pressure that represents one of the most important factors, which is necessary for the destruction of hard materials.

The second significant factor, according to Student criterion is the traverse speed $\mathrm{v}$ (Fig. 5). The third significant factor is the focusing tube diameter $d_{\mathrm{f}}$. It means that for optimisation purposes and for optimal set selection it is necessary to take into account the focusing tube wear that has a negative effect on cutting kerf width and surface roughness. The surface quality is dependent on the focusing tube wear that is very important for design of the algorithm for on-line control of AWJ technology. Fig. 3 illustrates the influence of the focusing tube wear in interaction with abrasive mass flow rate. It is evident that surface profile parameter $R a$ obtained from trace line $h=1 \mathrm{~mm}$ is dominantly affected by focusing tube wear. According to results obtained by the full factorial design, it results that the surface quality at stainless steel and aluminium cutting is mainly influenced by the focusing tube diameter.

\subsection{Focusing tube wear vs vibration emission}

The following figures are graphically interpreted measuring data of vibration by different traverse speed with using new focusing tube and worn focusing tube. For analysis signal the FFT (Fast Furrier Transformation) and Time analysis were used. Figs. 8 and 9 illustrate dependence of vibration and traverse speed. Fig. 9a) illustrates dependence composed datum scanning from workpiece into frequency area $0,5 \div 500 \mathrm{~Hz}$. Value of RMS reaches low levels, using the worn focusing tube in the range of speed shift from 50 to 100 traverse speed $\mathrm{mm} / \mathrm{min}$. Value of RMS for worn focusing tube increase above $v=100 \mathrm{~mm} / \mathrm{min}$. Using the new focusing tube the RMS values were significantly lower. The increased RMS values were measured at $v=20 \mathrm{~mm} / \mathrm{min}$ and at 200 traverse speed $\mathrm{mm} / \mathrm{min}$. Fig. 9b) graphically illustrates comparison of velocity RMS using new and worn focusing tube at different speed rates when sensor was placed on focusing tube.
Value of RMS is increasing with the increase of traverse speed in the use of new and worn focusing tube. Fig. 10 illustrates average values of peak found by determined rate of feed and by new and worn focusing tube. Worn focusing tube shows increased values and it has rising character. New tube shows lower values. Fig. 11 illustrates course at a traverse speed of $60 \mathrm{~mm} / \mathrm{min}$ by using worn focusing tube. Increased values down in the interval $700 \div 1200 \mathrm{~Hz}$ and in the interval $1400 \div 1600$ Hz. Fig. 12 illustrates course at a traverse speed of 60 $\mathrm{mm} / \mathrm{min}$ by using new focusing tube. Advance values were down in the interval $1100 \div 1400 \mathrm{~Hz}$. Overall lower values have been detected when using new focusing tube.

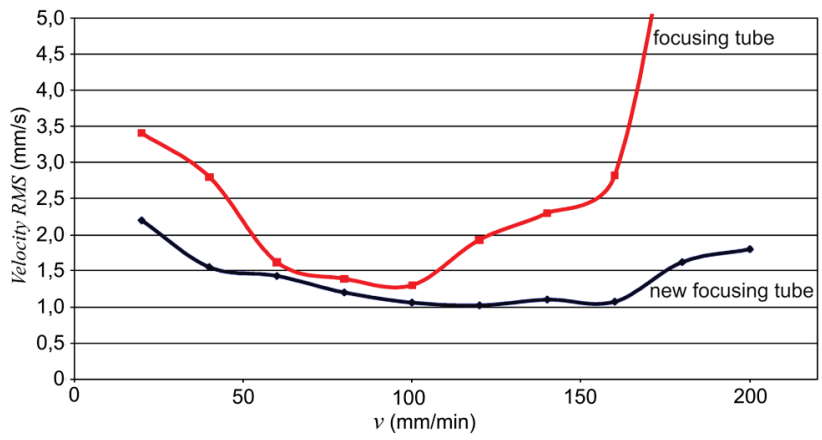

Figure 8 Comparison of velocity RMS using the new and worn focusing tubes at different traverse rate of cutting head (sensor placed on workpiece): a) red curve focusing tube ( 60 hours); b) blue curve - new focusing tube.

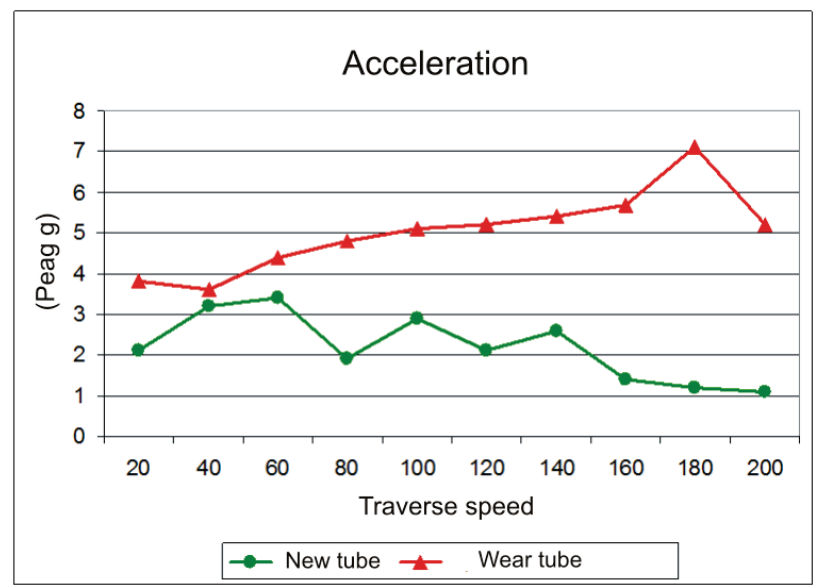

Figure 9 Comparison of average values of peak in dependencies on traverse speed

\section{Conclusion}

The paper describes the conclusions of the experiments where the influence of focusing tube with interaction of main selected factors as traverse speed, abrasive mass flow rate and pressure was studied by means of design of experiments on parameters of vibration and surface roughness parameter $R a$.

The main aim was to confirm a hypothesis whether the focusing tube wear has a significant effect on surface roughness quality and parameter of vibration [21]. From both experiments a significant effect on surface quality has been found that is presented in Pareto charts (Figs. 4 and 5) and in diagrams - Figs. 6 and 7. Measurement of vibration was carried out by different rate of feed and with applied worn and new focusing tube. 
The dependence between vibrations and focusing tubes wear has been observed. New tube is less sensitive to rate of feed than worn tube. Advanced values of vibration were recorded by using worn focusing tube as well as new tube. Measured signal has non-periodical character and signal level varies during cutting. The dependence between vibrations and focusing tubes wear has been observed; in the experimental conditions the cutting with the new focusing tube has induced less vibration. Based on the above mentioned conclusions, further experiments will be carried out to determine the connection between vibration and the surface quality and further measurements will be provided to find the dependence between vibration and technological conditions at materials cutting as well as the material properties.

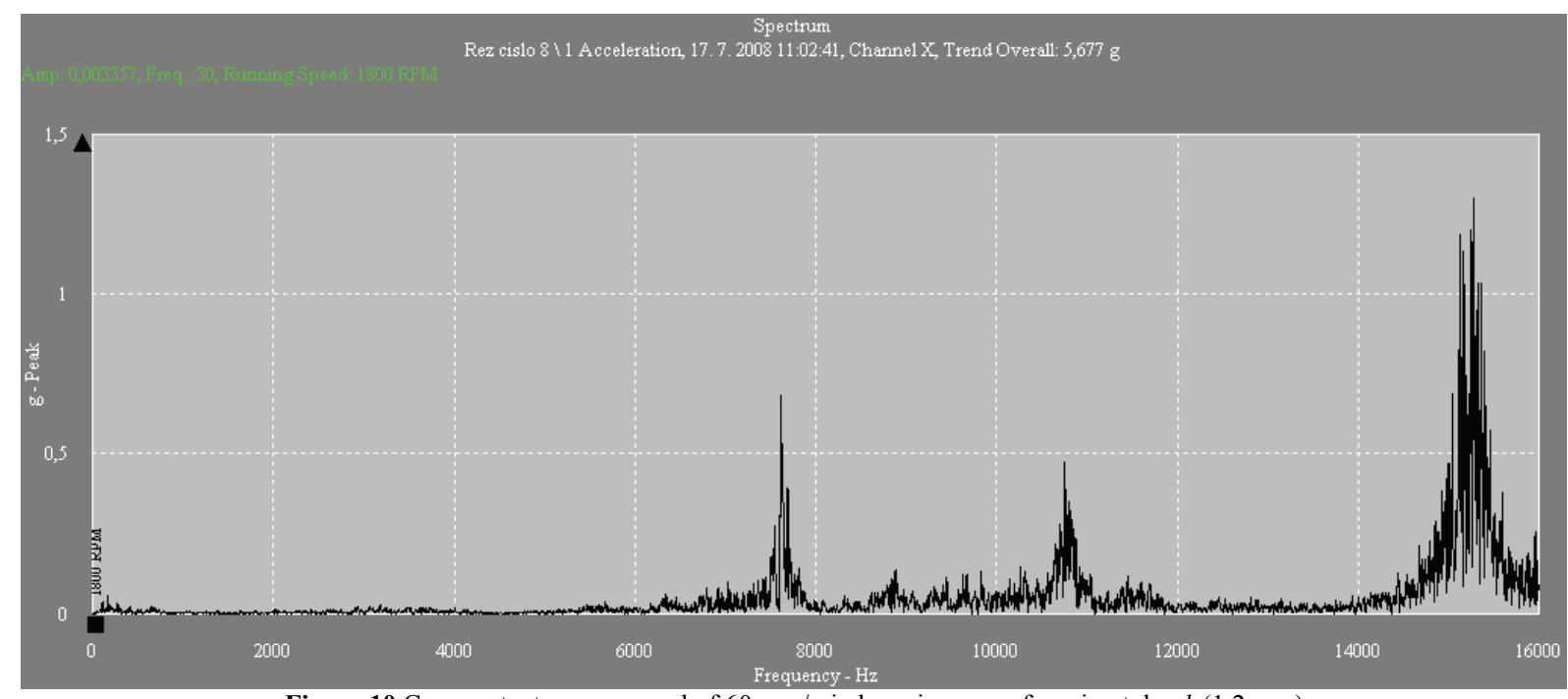

Figure 10 Course at a traverse speed of $60 \mathrm{~mm} / \mathrm{min}$ by using worn focusing tube $d_{\mathrm{f}}(1,2 \mathrm{~mm})$

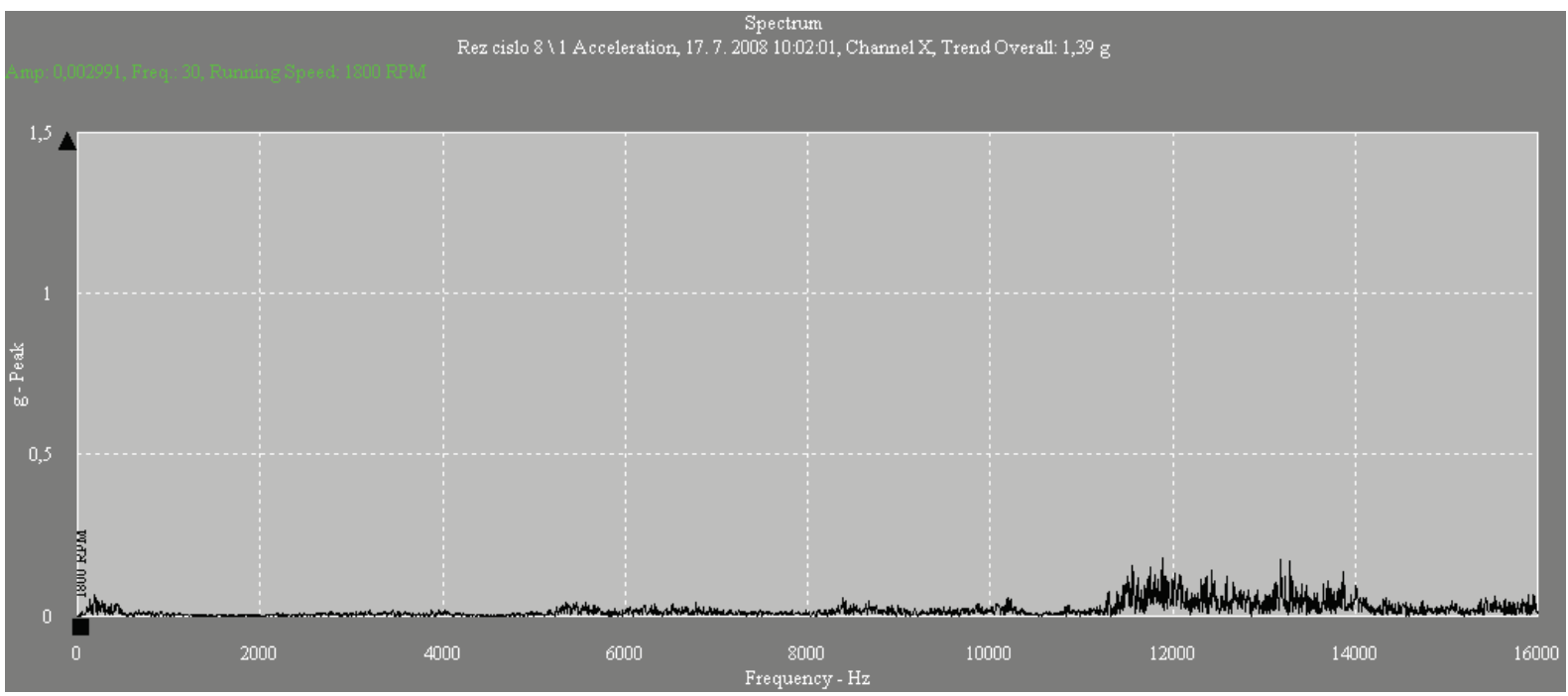

Figure 11 Course at a traverse speed of $60 \mathrm{~mm} / \mathrm{min}$ by using new focusing tube $d_{\mathrm{f}}=1 \mathrm{~mm}$

\section{Acknowledgement}

This work was supported by the Slovak Research and Development Agency under contract No. APVV-207-12 and VEGA 1/0972/11 and by OP VK System of Education for Personnel Assurance of Research and Development in the Sphere of Modern Trend of Surface Engineering - Surface Integrity, reg. Project No. CZ.1.07/2.3.00/20.0037.

\section{References}

[1] Folkes, J. Waterjet - An innovative tool for manufacturing. // Journal of Materials Processing Technology. 209, (2009), pp. 6181-6189. DOI: 10.1016/j.jmatprotec.2009.05.025
[2] Sharma, V. et al. Multi response optimization of process parameters based on Taguchi-Fuzzy model for coal cutting by water jet technology. // International Journal of Advanced Manufacturing Technology. 56, 9-12(2011), pp. 1019-1025.

[3] Hloch, S. et al. Disintegration of bone cement by continuous and pulsating water jet. // Tehnicki vjesnik-Technical Gazette. 20, 4(2013), pp. 593-598.

[4] Monkova, K.; Monka, P.; Vegnerova, P. et al. Factor analysis of the abrasive waterjet factors affecting the surface roughness of titanium. // Tehnicki vjesnik-Technical Gazette. 18, 1(2011), pp. 73-77.

[5] Hlaváček, P.; Brumek, J.; Horsák, L. Using of abrasive water jet for measurement of residual stress in railway wheels. // Tehnicki vjesnik-Technical Gazette. 19, 2(2012), pp. 387390.

[6] Boud, F.; Folkes, J.; Kinnell, P. A comparison of high pressure water jet nozzles in milling Inconel 718 and Martensitic steel BHR Group // $21^{\text {st }}$ International Conference 
on Water Jetting: Looking to the Future, Learning from the Past, (2012), pp. 379-393.

[7] Manu, R.; Babu, N. R. An erosion-based model for abrasive waterjet turning of ductile materials. // Wear. 266, (2009), pp. 1091-1097. DOI: 10.1016/j.wear.2009.02.008

[8] Hashish, M. A Model for Abrasive Water Jet Machining. // ASME Journal of Engineering Materials and Technology. 111, (1989), pp. 154-162. DOI: 10.1115/1.3226448

[9] Arola, D.; Ramulu, M. Material removal in abrasive waterjet machining of metals surface integrity and texture. // Wear 210, 1-2(1997), pp. 50-58. DOl: 10.1016/S0043-1648(97)000872

[10] Chao, J.; Geskin, E. Experimental Study of the Striation Formation and Spectral Analysis of the Abrasive Waterjet Generated Surfaces. $/ / 7^{\text {th }}$ American Water Jet Conference, Seattle, Washington, 1993, pp. 27-41.

[11] Dasgupta, R.; Modi, O. P.; Yadav, M. S. et al. Mechanism of material removal under high stress abrasive wear conditions under varying experimental conditions. // Journal of Materials Science Letters. 20, (2001), pp. 1837-1839. DOI: 10.1023/A:1012889432540

[12] Hloch, S.; Ruggiero, A. Online Monitoring and Analysis of Hydroabrasive Cutting by Vibration. // Advances in Mechanical Engineering. 2013, ID 894561, (2013), p. 10.

[13] Hreha, P. et al. Analysis of acoustic emission recorded during monitoring of abrasive waterjet cutting of stainless steel AISI 309. // Tehnicki vjesnik-Technical Gazette. 19, 2(2012), pp. 355-359

[14] Krenický, T.; Rimár, M. Monitoring of vibrations in the technology of AWJ. // Key Engineering Materials. 496, (2012), pp. 229-234. DOI: 10.4028/www.scientific.net/KEM.496.229

[15] Hreha, P. et al. Impact of abrasive mass flow rate when penetrating into a material on its vibration. // Tehnicki Vjesnik-Technical Gazette. 17, 4(2011), pp. 475-480.

[16] Montgomery, D. C. Design and Analysis of Experiments. Wiley, (2012), p. 752.

[17] Hreha, P.; Hloch, S. Potential use of vibration for metrology and detection of surface topography created by abrasive waterjet. // Int. J. Surface Science and Engineering. 7, 2(2013), pp. 135-151. DOI: 10.1504/IJSURFSE.2013.053699

[18] Zeleňák, M.; Valíček, J.; Klich, J.; Židková, P. Comparison of surface roughness quality created by abrasive water jet and $\mathrm{CO}_{2}$ laser beam cutting. // Tehnicki vjesnik-Technical Gazette. 19, 3(2012), pp. 481-485.

[19] Neelesh, K. J.; Vijay, K. J. Modeling of material removal in mechanical type advanced machining processes: a state of the art review. // Int. J. Mach. Tools Manuf. (2001), pp. 15731635.

[20] Hakan, T. Fuzzy AHP based decision support system for technology selection in abrasive water jet cutting processes. // Tehnicki vjesnik-Technical Gazette. 18, 2(2011), pp. 187191.

[21] Hreha, P. et al. Monitoring of focusing tube wear during abrasive waterjet (AWJ) cutting of AISI 309. // Metalurgija. 53, 4(2014), pp. 533-536.

\section{Authors' addresses}

Agáta Radvanská, Pavol Hreha, Lucia Knapčiková, Peter Monka

Faculty of Manufacturing Technologies

of Technical University of Košice with a seat in Prešov

Bayerova 1, 08001 Prešov, Slovak Republic

E-mail: agata.radvanska@tuke.sk

E-mail: radvanska.agata@gmail.com

\section{Jana Petrů, Tomáš Zlámal}

Faculty of Mechanical Engineering,

VŠB - Technical University of Ostrava,

17. listopadu 15, 70833 Ostrava-Poruba, Czech Republic 